\title{
GLL
}

00

\section{THE USE OF TERRESTRIAL LASER SCANNING IN THE PRESERVATION OF VALUABLE ARCHITECTURAL OBJECTS}

\author{
Izabela Piech, Przemysław Klapa, Piotr Szatan
}

\section{Summary}

In the present day, we are witnessing the dynamic development of our country. We observe a growing number of new construction investments, which are designed to meet the needs of the market. Streets are being widened to cope with the growing number of vehicles, modern office buildings and skyscrapers are being built in the largest Polish cities, which at the same time have valuable architectural objects in their oldest districts. Such objects, due to their age, are susceptible to damage, and thus to the threat that their value will be lost. Such damage may occur in the course of construction works that destabilize the soil structure, which may lead to damage to the building's foundations and, as a result, harm or destroy the most important structural elements of the monument. Another important factor is the operation of industrial plants that emit harmful substances, which have a negative impact on façades and other external elements, such as, for example, relief sculptures. It may be difficult and complicated to remove the effects of the risks described above if the documentation necessary to carry out protection or renovation works is incomplete or insufficiently detailed. A separate issue worth discussing are architectural objects made of perishable materials such as wood [Bernat et al. 2014]. There are many objects of wooden architecture in Poland, such as: Catholic and Orthodox churches, open-air museums, and other relics of bygone eras. Apart from the obvious threat of fire and its negative effects, one can also mention the negative impact of precipitation, whether in the form of rain causing the wood to soak and, as a result, to rot, or the risk of damaging the foundations during a flood. The listed threats have a direct and indirect impact on the structure of such historical buildings. Therefore, it is important to take care of their detailed survey, with the view to preserving and maintaining them. It is also worth mentioning a large number of castles located in our country. The condition of their structures is very diverse and ranges from newly restored buildings to those with only foundations left. In all cases, it is important to obtain accurate plans and models of these building objects. This will serve to preserve their dimensions and shapes. Such data can be used to develop documentation necessary to carry out reconstruction or renovation in order to return the building to its former glory, and thus obtain another object worth seeing.

\section{Keywords}

terrestrial laser scanning • survey $\bullet$ architecture 


\section{Introduction}

Thanks to the use of a terrestrial laser scanner, it is possible to carry out an architectural and construction survey and inventory in a much faster and more accurate way than by using traditional methods, for instance with non-metric cameras or metric cameras. The task of the survey is to accurately depict the existing spatial layout, functional and technical structure as well as the decor of a complex of architectural objects, individual building structures, or their parts, based on geodetic and photogrammetric measurements [Uchański et al. 2008]. Inventory documentation prepared on the basis of laser scanning measurements can be presented in the form of vector graphics, flat projections, plans, views, as well as three-dimensional models. These models can be used to make mock-ups in the 3D printing technology [Major and Minda 2016]. The 3D laser scanning technology is now also used in the preparation of inventory documentation for historic buildings and complex architectural details, e.g. relief sculptures. The first results of the measurements that had been made with the use of tachymeters or laser scanners, for the purpose of documenting architectural details, were presented by Mierzwa and Rzonca [2003].

We find numerous examples in the literature of studies using terrestrial laser scanning [Mikulski 2013, Hejmanowska et al. 2015, Kwoczynska et al. 2016, Klapa et al. 2017]. Survey documentation makes it possible to assess the condition of the building object, plan maintenance and modifications, and, above all, recreate the elements of the building object in the event of their destruction. For the conservation of monuments, the most comprehensive and accurate inventory of all architectural details turns out to be extremely valuable, allowing for their subsequent reconstruction or planning for their conservation.

A survey conducted using traditional geodetic methods allows for the development of technical documentation, which consists of roof and floor projections as well as architectural cross-sections of the building object and elevation drawings, but it does not provide full information about the details of the building. Monument protection authorities, in the performance of detailed surveys and inventories of architectural details, apply, inter alia, hand-drawn sketches, descriptive and photographic documentation, or plaster casts. Nevertheless, new technologies, such as laser scanning, may turn out to be very useful and can potentially significantly accelerate the process of surveying, inventorying, and documenting the building's architecture and details.

The use of laser scanning as a measurement method makes it possible to register the actual and accurate condition of the historic building before the start of conservation works and provides precise data necessary to create architectural documentation and perform renovation. The task of the survey is to accurately depict the existing spatial layout, functional and technical structure as well as the decor of a complex of architectural structures, individual building objects, or their parts, based on geodetic and photogrammetric measurements. [Uchański et al. 2008]. In the event that the scanned monument is intended for demolition and then reconstruction with the use of modern materials, laser scanning products may be the only source of information about the object that no longer exists. Due to the high level of detail of the data, it is also possible 
to build the same object in a different location - if in the previous place there were conditions that threatened the structure of the historic building [Bernat et al. 2014].

Laser scanning products can also provide a source of data for analysing the condition of the structure of a historic building, examining the verticality of elements as well as the shape and structure of existing deformations. Interpretation of the value of the intensity of the laser beam reflection makes it possible to study the condition of the structure and the type and degree of wear of the materials from which the historic building was made [Boehler et al. 2004].

Despite the fact that an instrument such as a terrestrial laser scanner is a complex device with a complex and advanced structure, its operation is simple. It comes down to setting the instrument in a specific position (station), and introducing basic parameters. The measurement is performed after starting the device, and its effects are more accurate than when using classical measurement and photogrammetric methods. This procedure also takes much less time, and thus increases the efficiency of work. The output data obtained in this process, called the point cloud, represent the object under measurement, and facilitate the determination of the location of its elements, even the smallest ones. If we are in possession of the coordinates of the measuring station, it is possible to determine the position of the measured points in the system in which the coordinates of the station had been set. If there is a need to use more than one point cloud, it is possible to combine them, as long as a sufficient number of common points were measured in both measurements [Bernat et al. 2016]. The performance of surveying works related to the inventory leads to the creation of documentation aimed at presenting the current technical condition of the building, its spatial situation, as well as showing its function. The aforementioned documentation can be presented in a graphic, descriptive, or photographic form, in compliance with appropriate standards. It constitutes the basic material when performing works such as renovation, modernization or inventory.

\section{Studied object}

In this work, a building located at the Hugo Kołłątaj University of Agriculture in Krakow at Balicka 253A was designated as the research object. The building currently has an educational function; it houses rooms in which practical classes are held, as well as storage space for research and teaching instruments. Inside the building, there are also rooms used for administrative purposes as well as offices of individual university employees. Historically, this building was part of a farm located in the area currently occupied by the Faculty of Environmental Engineering and Land Surveying. In all probability, it used to serve as a farm building, intended for the storage of grains and the breeding of livestock. Before the rights to the building were taken over by the Polish government, and consequently by the University of Agriculture, the area and all buildings were owned by Adolf I Czesław Schoen, who purchased the property in 1880 [Fedor 2013]. The building is rectangular in shape and has two storeys. It is built of large stone blocks, which means that it has very thick walls and very narrow and small windows. The roof is covered with ceramic tiles. The façade is white, covered with plaster. The windows are not original; 
they were probably replaced during renovation works, and more windows were added to the roof surface, which would not have matched the original purpose of the building. On the right, there is a three-storey extension, which was built later, as can be inferred from a different building style and the use of different materials. A characteristic element that does not match the original purpose of the building is a balcony connected to the vestibule. It is worth mentioning the decorative, wooden elements under the thatched roof. To sum up, despite being adapted to its current function, the studied building has retained structural elements that are worth preserving and documenting (Fig. 1).

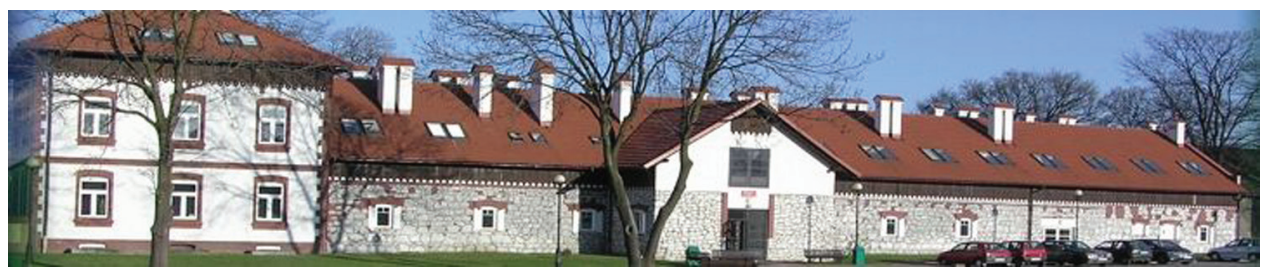

Photo: Authors' study

Fig. 1. Building belonging to the University of Agriculture in Krakow

\section{Methodology}

Before starting the essential works related to the inventory measurement using the 3D laser scanning technology, the course of fieldwork should be carefully planned. For this purpose, we used data obtained and processed during a field inspection as well as data obtained from other sources, e.g. literature on the subject, or Google maps.

The object was measured using a Leica ScanStation P40 laser scanner. In order to combine point clouds from individual stations into one data set, characteristic elements of the building clearly identified on both stations were used. The entire façade of one of the external walls of the building was measured. In order to perform the necessary measurements covering the entire range of the wall, it was necessary to place the scanner on two separate stations, 10 metres away from the scanned object. The accuracy of the measurement in the horizontal and vertical planes was set at 0.002 metres on each of the stations. $360^{\circ}$-range scans on all measuring stations were performed. The time needed by the instrument to perform the assigned work was about 8 minutes and 36 seconds in each station. During the chamber works related to the initial processing of the point cloud, the dedicated software from the manufacturer Leica Cyclone was used. At a later stage of the works, MicroStation V8i and Leica Cyclone 3DR were used to process and create the documentation.

\subsection{Processing of the obtained data}

After the fieldwork related to the measurement had been completed, the data thus obtained was pre-processed before further processing. The initial activities that had to 
be performed included, primarily, combining the point clouds from individual stations into one collective cloud. Having combined the data, we proceeded to identify any measurement distortions, and to determine which scanned elements do not belong to the studied building object. Then all the points that were not designated for further processing had been deleted. The Leica Cyclone software was used to perform these activities. The first task to perform was to create a database with the 'add database' command, and import data from all of the measurement stations. The next step was to orient the point clouds in relation to each other, and combine them into one collective point cloud that would represent the shape of the building object that was subjected to the measurement. Characteristic elements of the building, measured from both stations and clearly identified, had been used to combine the data from individual stations. This amalgamation was possible thanks to the use of the Vertex function. The arrangement of individual vertices on the building's elements is shown in Figures 2, 3 and 4.

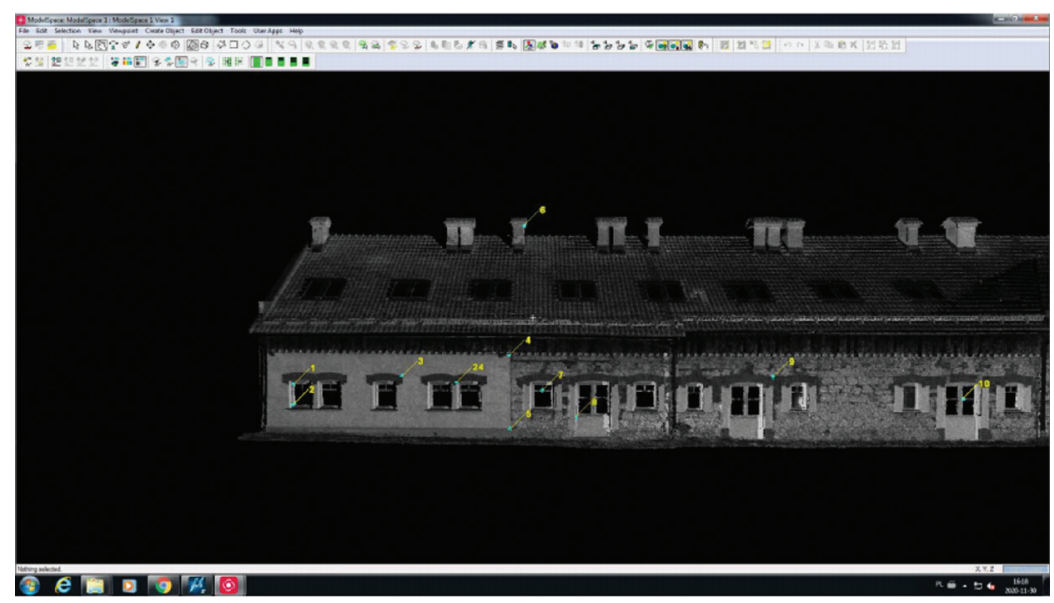

Source: Authors' study

Fig. 2. Placement of the vertices in the left part of the building

In order to maintain the required level of accuracy, 24 vertices had been defined, and their distribution was planned and executed in such a way that there was only one vertex on one vertical and horizontal plane. These activities had a key impact on obtaining the level of orientation error that had been assumed in the project, that is, not exceeding 0.05 metres (Table 1 ).

Having combined the point clouds from individual stations and having executed the orientation process, we were able to proceed to the next activity, which was removing elements that do not constitute the object of the measurement. The result thus produced was a point cloud showing only those elements that would be subject to further processing. In this particular case, the obtained effect is a cloud of points representing the elevation and the roof of the object under study (Fig. 5). 


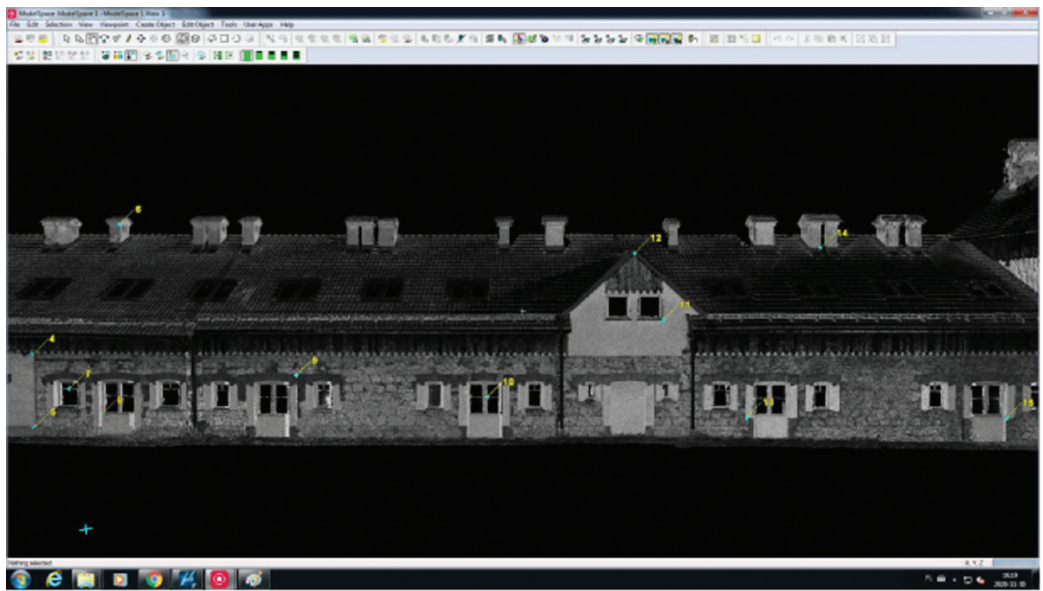

Source: Authors' study

Fig. 3. Placement of the vertices in the central part of the building

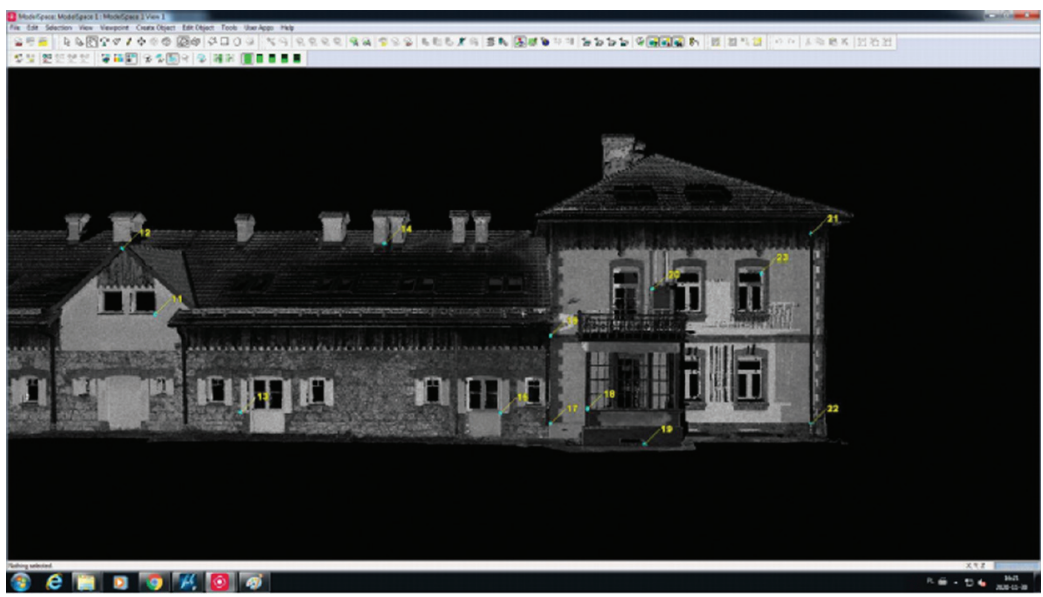

Source: Authors' study

Fig. 4. Placement of the vertices in the right part of the building

In order to facilitate work while uploading, the function of selecting and dragging a point cloud has been enabled. This significantly accelerated the work on the project, as the drawn lines did not interact with the cloud. Thanks to the described methods and tools for creating views, drawings were made showing the building's elevation and projections (Figs 6, 6a, 7, and 8), which represent individual fragments of the building. 
Table 1. Orientation report

\begin{tabular}{|l|l|}
\hline \multicolumn{1}{|c|}{ Status } & \multicolumn{1}{c|}{ VALID Registration } \\
\hline Mean Absolute Error: for Enabled Constraints & $0.015 \mathrm{~m}$ \\
\hline Mean Absolute Error: for Disabled Constraints & $0.000 \mathrm{~m}$ \\
\hline Date & 2020.11 .30 15:00:56 \\
\hline Database name & Elewacja_Balicka \\
\hline ScanWorlds: Station-001 & SW-001 \\
\hline ScanWorlds: Station-002 & SW-002 \\
\hline
\end{tabular}

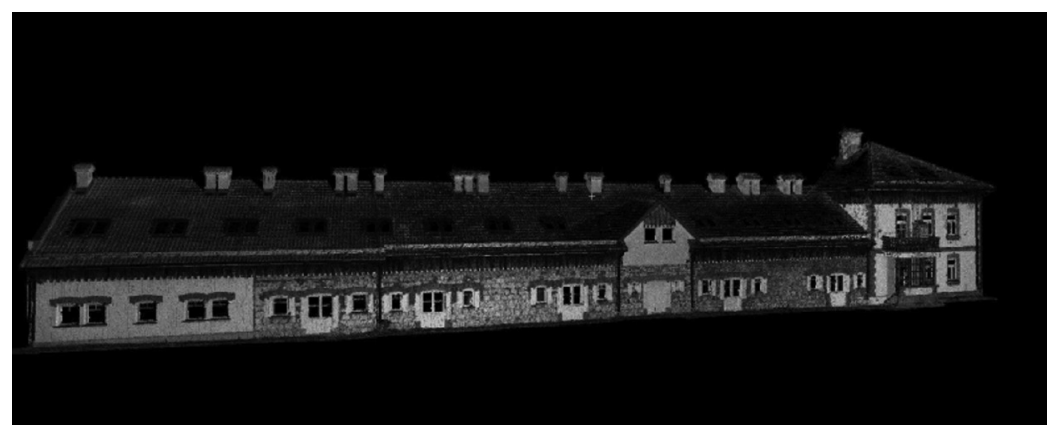

Source: Authors' study

Fig. 5. Edited (adjusted) point cloud

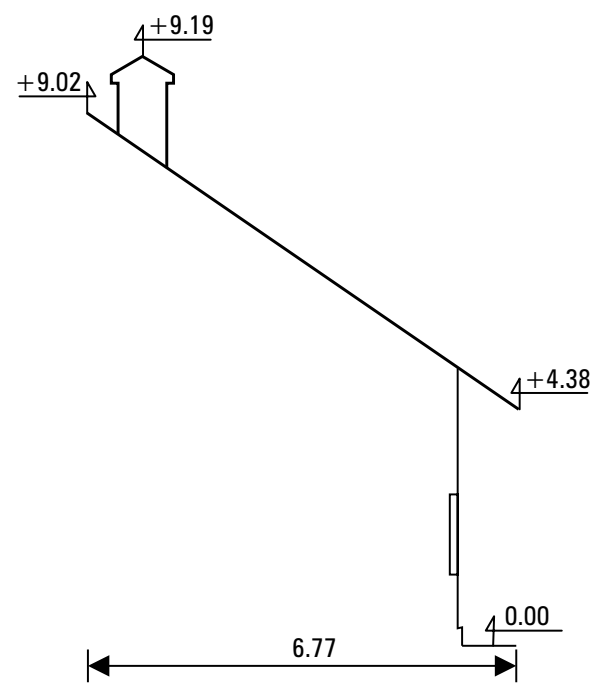

Source: Authors' study

Fig. 6. Side projection of the building at Balicka 253a, from the left 


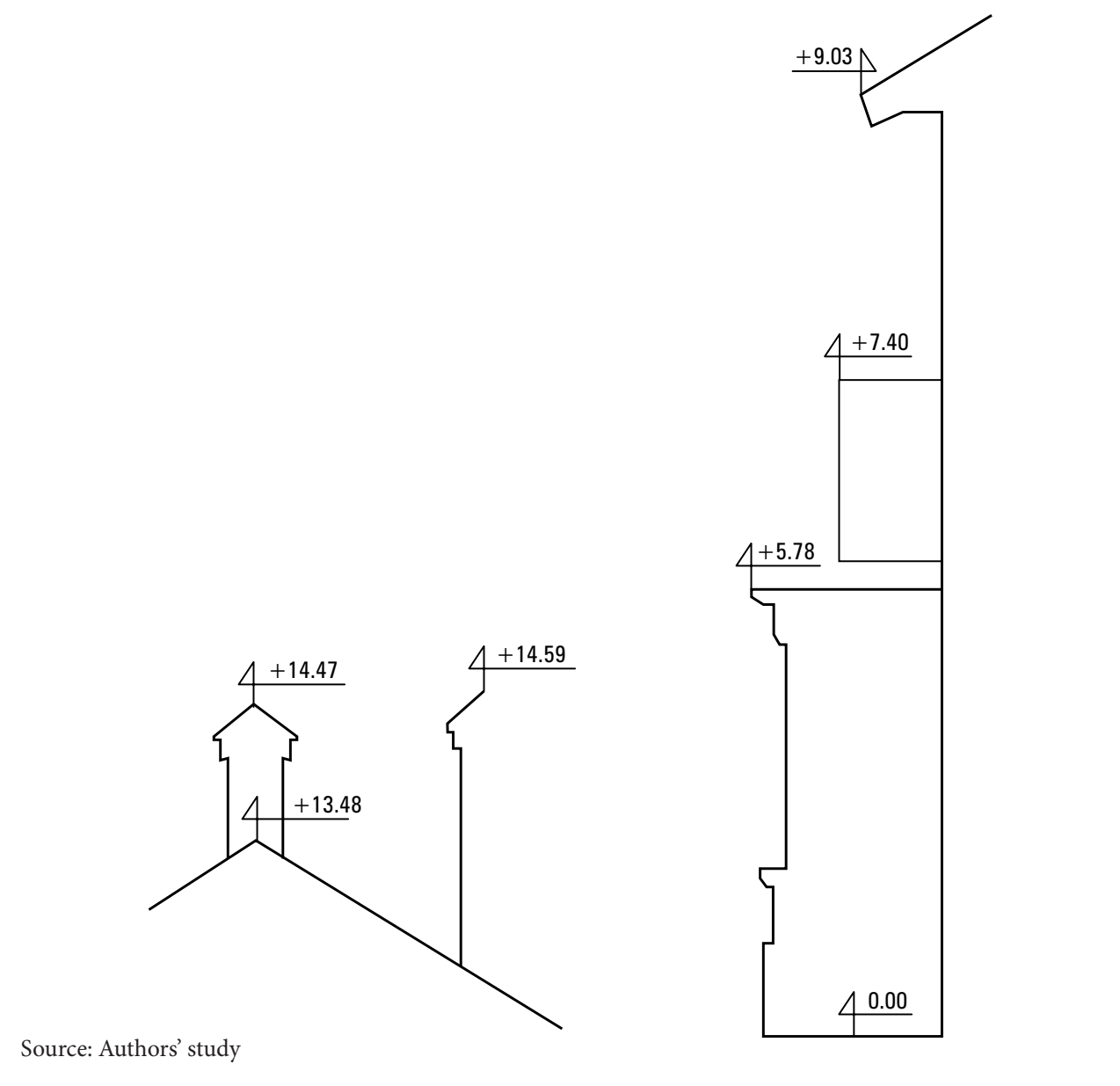

Fig. 6a. An enlarged fragment of the side projection of the building at Balicka 253a

After all the elements had been drawn, the drawings were measured with the 'Measure Distance' tool. The obtained measures correspond to the actual dimensions, because the cloud representing the object under development had been displayed on a 1:1 scale throughout the process. Then, all the measured elements were described with corresponding measures. As a result, documentation was created that represented the appearance, shape, and size of the studied object and its elements (Fig. 9).

Due to the high level of detail of the examined object, it was decided that additional documentation should be prepared, in the form of a mesh representing the façade of the building. The Leica Cyclone 3DR software was used to generate this material. 9.1 The Leica Cyclone3DR meshing process is illustrated in Figure 10.

End result of the discussed process is the creation of a mesh that can be further processed or used as a material illustrating the details of the measured objects (Fig. 11). 


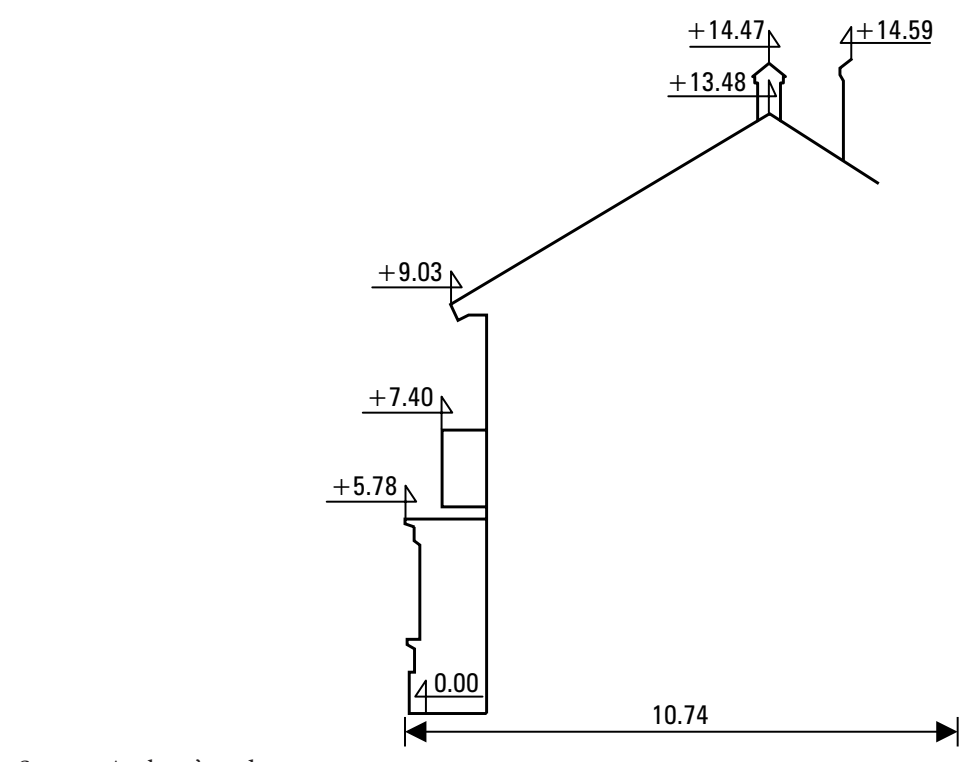

Source: Authors'study

Fig. 7. Side projection of the building at Balicka 253a, from the right

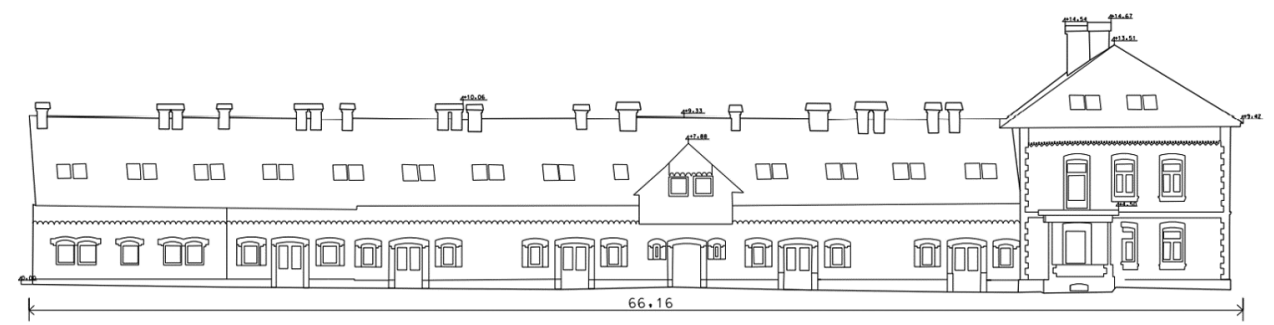

Source: Authors' study

Fig. 8. Elevation of the building at Balicka 253a

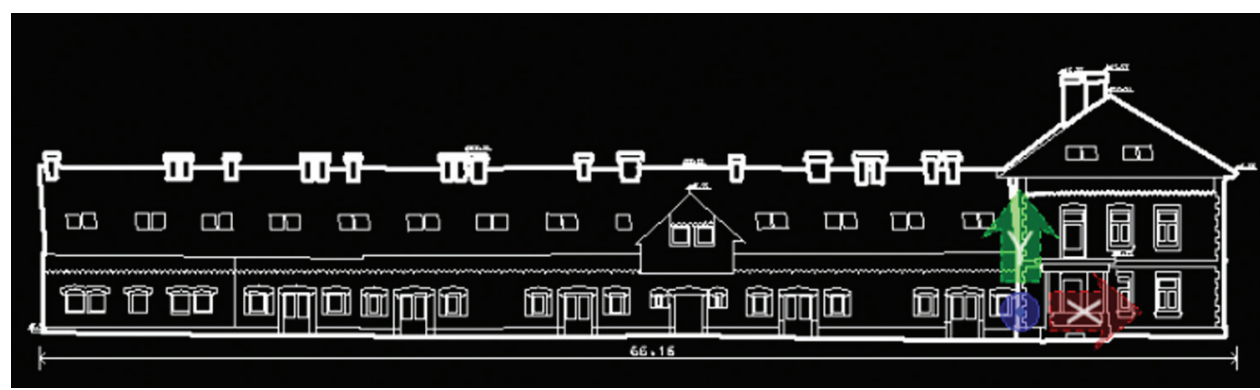

Source: Authors' study

Fig. 9. Drawn contour lines of the elevation view 


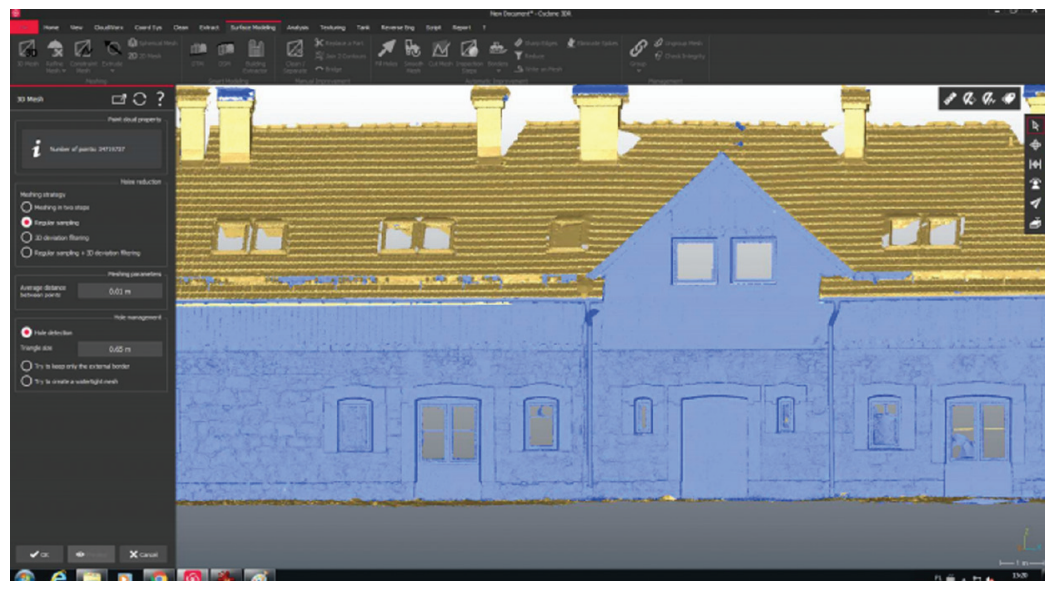

Source: Authors'study

Fig. 10. Parameters of mesh generation process

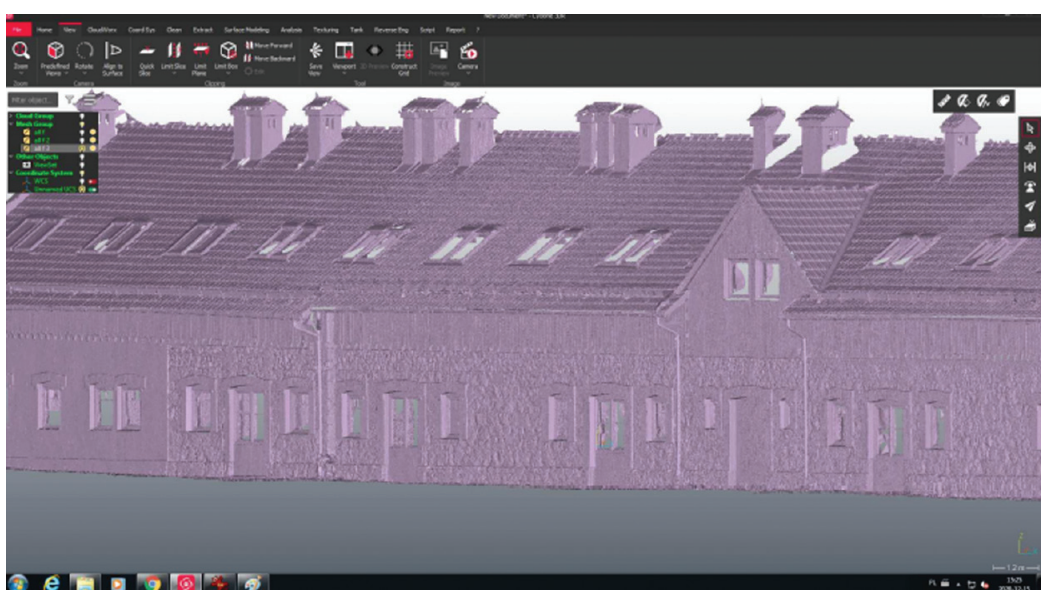

Source: Authors' study

Fig. 11. Mesh representing a fragment of the elevation

\section{Conclusions}

The purpose of this work was to present the possibilities of using terrestrial laser scanning in order to preserve valuable architectural objects. The object under study was the building located at number 253a in Balicka street, belonging to the Faculty of Environmental Engineering and Land Surveying of the University of Agriculture in Krakow. The instrument used for this purpose was the Leica ScanStation P40 terrestrial laser scanner. A fragment of the building was selected for analysis, namely, its 
external façade. During the chamber works, the point clouds from individual stations were combined and all points that were not part of the study had been excluded. The Leica Cyclone program was used for this purpose. After completing the aforementioned operation, the files from the program were saved in the .pts format and then converted to the .pod format using the Bentley Pointools PODcreator software. The final effect of the work is the creation of side views and projection of the elevation, as well as the mesh representing the building's details. The drawings were made using the MicroStation V8i software, and the mesh was developed in the Leica Cyclone 3DR application. During the drawing process, a number of tools offered by the program were used. Dimensioning was also made in accordance with the applicable rules. To conclude, terrestrial laser scanning is a technology that can be successfully used to protect valuable architectural objects. The speed of obtaining data using this technology, and the accuracy of the data itself, enable the preservation of the most complex details, as well as the creation of many studies from the same measurement. Thanks to this flexibility of data, it is possible to create both classic architectural and construction studies, and modern 3D models. However, the processing itself requires a lot of time and a considerable computing power, which, combined with the price of a terrestrial laser scanner and the software required for the performance of the work, significantly hinders the mass-scale use of this technology, despite its latent potential.

\section{References}

Bernat M., Byzdra A., Chmielecki M., Laskowski P., Orzechowski J., Rzepa S., Szulwic J., Ziółkowski P. 2016. Zastosowanie naziemnego skaningu laserowego i przetwarzanie danych: inwentaryzacja i inspekcja obiektów budowlanych. Przegląd technologii i przykłady zastosowań. Wydawnictwo Polskiego Internetowego Informatora Geodezyjnego, ser. Geomatyka, 18.

Bernat M., Janowski A., Rzepa S., Sobieraj A., Szulwic J. 2014. Studies on the use of terrestrial laser scanning in the maintenance of buildings belonging to the cultural heritage. 14th International Multidisciplinary Scientific GeoConference. SGEM, 20.

Fedor F. 2013. Krótka historia dworu hr. Darowskich w Mydlnikach. Kraków.

Hejmanowska B., Kaminski W., Przyborski M., Pyka K., Pyrchla J. 2015. Modern remote sensing and the challenges facing education systems in terms of its teaching. Edulearn 15 Proceedings. 7th International Conference on Education and New Learning Technologies. Barcelona, Spain, 6549-6558.

Klapa P., Mitka B., Zygmunt M. 2017. Study into Point Cloud Geometric Rigidity and Accuracy of TLS-Based Identification of Geometric Bodies. World Multidisciplinary Earth Sciences Symposium (WMESS). IOP Conf. Series: Earth and Environmental Science, 95, 032008.

Kwoczyńska B., Litwin U., Piech I., Obirek P., Sledz J. 2016. The Use of Terrestrial Laser Scanning in Surveying Historic Buildings. Proceedings of 2016 Baltic Geodetic Congress (Geomatics), 263-268, IEEE. doi: 10.1109/BGC.Geomatics.2016.54

Major M., Minda I. 2016. Zastosowanie technologii druku przestrzennego w budownictwie. Zeszyty Naukowe Politechniki Częstochowskiej, ser. Budownictwo, 22, 238-247.

Mierzwa W., Rzonca A. 2003. Skanowanie powierzchni jako nowa metoda rejestracji i interpretacji szczegółów architektonicznych. Archiwum Fotogrametrii, Kartografii i Teledetekcji, 13, 427-434. 
Mikulski S. 2013. Metody triangulacji laserowej w skanerach trójwymiarowych. Czasopismo Naukowe Politechniki Poznańskiej, 75, Poznań.

Rozporządzenie Ministra Rozwoju z dnia 18 sierpnia 2020 r. w sprawie standardów technicznych wykonywania geodezyjnych pomiarów sytuacyjnych i wysokościowych oraz opracowywania i przekazywania wyników tych pomiarów do państwowego zasobu geodezyjnego i kartograficznego.

Uchański J., Falkowski F., Sörensen L. 2008. Problematyka standaryzacji w dziedzinie inwentaryzacji obiektów architektonicznych technikami skaningu laserowego naziemnego. Archiwum Fotogrametrii, Kartografii i Teledetekcji, 18.

Dr inż. Izabela Piech

University of Agriculture in Krakow

Department of Land Surveying, Cadastre and Photogrammetry

30-198 Kraków, ul. Balicka 253a

Correspondence address:

31-120 Kraków, al. Mickiewicza 21

e-mail: rmpiech@cyf-kr.edu.pl

ORCID: 0000-0002-6710-4387

Dr inż. Przemysław Klapa

University of Agriculture in Krakow

Department of Land Surveying, Cadastre and Photogrammetry

30-198 Kraków, ul. Balicka 253a

Correspondence address:

31-120 Kraków, al. Mickiewicza 21

e-mail: przemyslaw.klapa@urk.edu.pl

ORCID: 0000-0003-1964-7667

Inż. Piotr Szatan

University of Agriculture in Krakow

Department of Land Surveying, Cadastre and Photogrammetry

30-198 Kraków, ul. Balicka 253a

Correspondence address:

31-120 Kraków, al. Mickiewicza 21

e-mail: piotr.szatanh@student.urk.edu.pl 